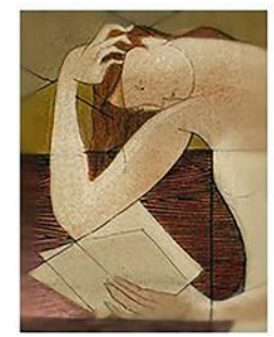

\title{
Os músicos cariocas no século XIX na perspectiva de Machado de Assis
}

Gabriela Guindani ${ }^{1}$

\begin{abstract}
Houve sol, e grande sol, naquele domingo de 1888, em que o Senado votou a lei, que a regente sancionou, e todos saímos à rua. Sim, também eu saí à rua, eu o mais encolhido dos caramujos, também eu entrei no préstito, em carruagem aberta, se me fazem favor, hóspede de um gordo amigo ausente; todos respiravam felicidade, tudo era delírio. Verdadeiramente, foi o único dia de delírio público que me lembra ter visto. Assim escrevia Machado de Assis numa crônica de 14 de maio de 1893, recordando o grande dia da abolição.
\end{abstract}

(MEYER, 2005, p. 35).

Resumo: A autoria é parte importante na percepção de uma obra porque o sujeito que se forma a partir de determinadas experiências limitadoras, como foi o caso do negro no Brasil do século XIX, é, certamente, diferente daquele que corre na linha dos privilégios. No campo da literatura, essa verdade se torna especialmente assombrosa se pensarmos no caso de Machado de Assis. A omissão do fato desse autor não ser branco e, portanto, não desfrutar dos privilégios que a cor clara da pele traria durante um dos momentos da história em que a escravidão foi pauta importante revela uma crueldade por fazer crer que a figura por trás dos mais grandiosos livros da literatura brasileira teria pertencido a uma elite branca; e isso, somado ao papel dos escritores e artistas negros no paradigma da literatura e também da música, expressa o quanto ainda temos que lutar, como sociedade, para que a arte possa ser considerada livre e igualitária. Pensando nisso, este trabalho discute a representação, em três contos ( $O$ machete, Um homem célebre e Cantiga dos esponsais), que um escritor mulato, como eventualmente Machado é descrito, faz de artistas músicos, igualmente mulatos ou negros, a partir da premissa de que a vida de um autor se revela, através de rastros, em tudo que ele produz.

Palavras-chaves: Machado de Assis; contos; música; século XIX;

Abstract: Authorship is an important part of the perception of a work because the subject who is formed from certain limiting experiences, as was the case of the slaves in 19th century in Brazil, is certainly different from those who run along the line of privileges. In the field of literature, this truth becomes especially astonishing if we consider the case of Machado de Assis. The omission of the fact this author is not white and, therefore, does not enjoy the privileges that the bright color of the skin would bring during one of the moments in history when slavery was an important issue, reveals a cruelty for making believe that the figure behind the most great books of Brazilian literature would have belonged to a white elite; and this, added to the role of black writers and artists in the paradigm of literature and also of music, expresses how much we still have to fight, as a society, so that art can be considered free and equal. With this in mind, this work discusses the representation, in three short-stories (O machete, Um homem célebre and Cantiga dos esponsais), that a mulato writer, as Machado is eventually described, makes of musicians, equally mulatos and blacks, from the premise that an author's life is revealed, through traces, in everything he produces.

Keywords: Machado de Assis; short-stories; music; 19th century;

\footnotetext{
${ }^{1}$ Mestranda em Letras na Universidade Federal do Rio Grande do Sul (UFRGS).
} 

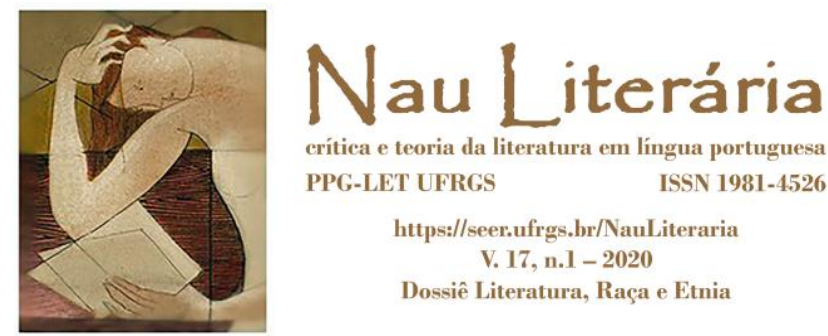

A Metrópole, na pessoa de seus mais altos dignitários, estava a caminho da capital do Vice-Reino, onde ia ser instalado o Governo central até que se normalizasse a situação. Eis a mensagem que trazia o brigue Voador. (ANDRADE, 1967, p. 9).

E assim, dizemos: "O início do século XIX foi marcado pela vinda da família Real para o Brasil". Semântica. Uma pequena troca de verbos transforma D. João VI de refugiado em explorador; e esse mesmo eufemismo se faz presente em vários momentos da história de nosso país nas mais diversas formas de expressão - na arte, na literatura e, ainda, na arquitetura.

Uma notícia recente, manchete do jornal Veja São Paulo, na versão virtual, ficou famosa nas redes sociais: um escravo paulista, responsável pela construção e pela restauração de algumas igrejas importantes durante o século XVIII, passou a ser reconhecido, duzentos anos após sua morte, como o arquiteto responsável pela Catedral da Sé paulista. Longe de discutir a legitimidade da notícia, a importância do jornal ou as questões legais implicadas na nomeação dos responsáveis pelas obras arquitetônicas de São Paulo, o fato de a história convenientemente esquecer alguns nomes (nunca aleatórios) ou diminuir a atuação de determinados sujeitos a partir do indicador cor $d a$ pele revela a cruel e desfavorável condição que o negro encontrou no Brasil quando, à força, foi trazido como escravo.

No decorrer da história, muitos outros nomes, certamente, foram omitidos, calcados nesse marcador biológico; e, em se tratando de literatura, um dos casos mais notáveis que discute a questão racial é o de Machado de Assis. Pouco é dito - às vezes nada é dito - sobre a ascendência do autor e essa omissão - deliberada ou por ignorância - revela o embranquecimento que legamos ao que consideramos relevante no campo da produção literária, artística, etc.

Contudo, adicionar nomes ao paradigma (seja literário ou arquitetônico) parece uma tarefa árdua - porque sem previsão para ser concluída - e soa como pouco produtiva; a criação de outro(s) paradigma(s) tampouco parece fazer sentido. Conformidade, então, passa longe de ser uma medida adequada. Talvez a resposta esteja 

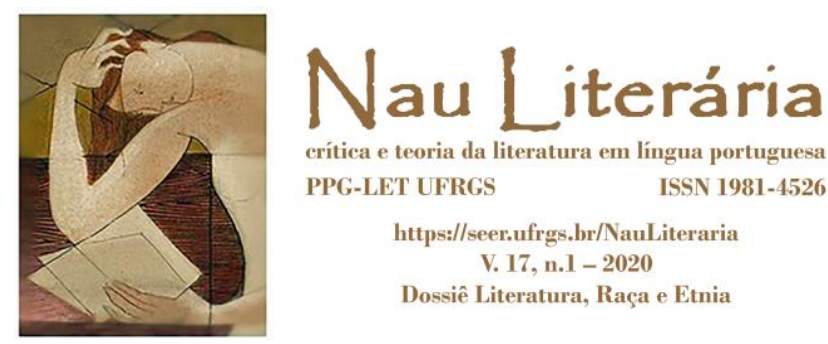

na definição do que seja aceitação. Aceitar que possam existir versões de uma mesma história que não foram descobertas e talvez nunca o sejam não nos impede de continuar procurando, mas deve nos tranquilizar quando sentirmos que isso não basta. A rebeldia estará, então, em estudar o maior nome da literatura brasileira sob o pretexto de dizê-lo mulato, bem como a imagem que esse escritor constrói do negro como "um artista menor" e o motivo de isso ainda implicar as produções culturais do nosso tempo.

\section{Da vinda da família real e dos investimentos feitos no Rio de Janeiro}

O século XIX foi marcado por mudanças econômicas e políticas em todo o mundo, decorrentes, sobretudo, de movimentos iniciados nos anos anteriores, durante o século das luzes. A revolução industrial e, mesmo, a revolução francesa - que resultou em conflitos militares pela expansão do território e destacou Napoleão Bonaparte como herói nacional - são exemplos de ações cujos reflexos são sentidos no início dessa era e que contribuem para analisar a situação do Brasil enquanto colônia, bem como sua relação com a metrópole, direta beneficiária, por anos, dos produtos e da renda desse território. É, ainda, durante esse período que o império britânico adquire supremacia e influencia as demais nações com suas medidas econômicas, em especial referentes à abolição do tráfico de escravos, uma vez que, nesse século, com as extensões ao interior da África, tal prática, pela intensidade, movimentou grande parte do capital mundial.

Nesse cenário, apresentando um desenvolvimento lento e tardio em relação ao resto da Europa no que diz respeito à industrialização e com as guerras napoleônicas surgindo como ameaças iminentes, a corte portuguesa se estabelece no Brasil em 1808, numa ação que, convenientemente, designa-se "viagem para a colônia". A "vinda da família real” que representou, em verdade, uma fuga financiada pela Inglaterra fez do Rio de Janeiro a capital e promoveu, assim, uma reforma urbana e cultural em um país que, tal como a metrópole que o geria, exibiria transformações políticas vagarosas e pouco expressivas. 


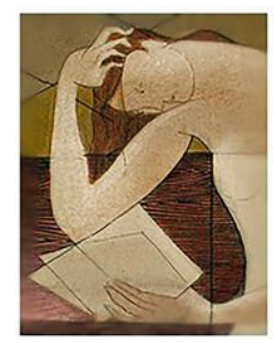

Dom João VI decreta, como primeiras medidas para esse novo reinado, a abertura dos portos brasileiros às nações amigas, o que vem a beneficiar, de maneira compensatória, os produtos britânicos. Voltaremos a essa consideração mais tarde. Seguido desse ato, a colônia passa a contar com investimentos que, antes, eram exclusivos da metrópole - especialmente nas áreas da cultura e da arte.

Foi um alvoroço sem precedente. Como num passe de mágica, nova fisionomia ganhava a cidade. Não foi apenas a residência do vice-rei que levou pintura nova por dentro e por fora. Não foram apenas as igrejas e demais edifícios notáveis que se fizeram, num piscar de olhos, mais reluzentes; nem as construções iniciadas, que se aprontaram como por encanto. A par disso, toda uma série de providências foi assentada com o objetivo de mostrar ao mundo de exilados que vinha engrossar a população da cidade o que esta era na sua acolhedora personalidade. (ANDRADE, 1967, p. 10).

Contanto que o rei estivesse confortável, bem como sua comitiva de nobres certa da excelência cultural portuguesa, à cidade do Rio de Janeiro era prometido um futuro cosmopolita, baseado na presunção de uma etiqueta e de uma civilidade à la Europa. A construção de novos teatros, a impressão de livros e jornais e a introdução, especificamente no campo da música - arte carinhosamente apadrinhada por Dom João VI -, de instrumentos de origem europeia passam a sustentar novas lógicas de relações sociais, bem como novas percepções de gosto às quais essa cidade se adaptou e com as quais contribuiu. Atrelados à música, novos ritmos - como a valsa e a quadrilha - logo são incrementados à cultura local, abrindo caminho para a popularização de outros estilos a partir do meio do século, como a polca.

Se a abertura dos portos pode ser considerada uma ação econômica, a criação da Capela Real ${ }^{2}$ é um exemplo de como o príncipe regente entendeu de modificar a organização sociocultural desse território para fazê-lo semelhante a Lisboa. Como narra Ayres Andrade, a incumbência, em 1808, da Igreja dos Carmelitas como Sé Catedral com caráter de urgência garantiu os alicerces à instituição que viria a ser importante para a produção musical neste lado do Atlântico. Sob o comando do padre José

\footnotetext{
${ }^{2}$ Igreja de Nossa Senhor do Carmo da Antiga Sé, no centro histórico do Rio de Janeiro, foi designada, pela proximidade do centro administrativo instaurado na colônia, como Capela Real Imperial e, mais tarde, como Catedral do Rio de Janeiro.
} 


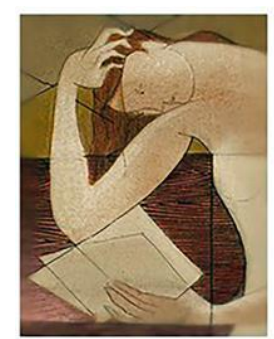

Maurício Nunes Garcia, que fora nomeado compositor titular em 1789 (ANDRADE, 1967), então, está a Capela Real instalada ao lado³ de Dom João VI e regida por um mulato descendente de escravos, fato que, por certo, não significou, para a história da música brasileira, o mesmo que para a dos movimentos negros.

Uma apresentação dos cantores e instrumentistas pensada e coordenada por um padre não-branco quando da primeira missa celebrada pelo desembarque da família real revelou uma surpresa que o príncipe regente não esperava encontrar em terras tão longínquas: a beleza na execução musical de atos religiosos. Contudo, a seleção do repertório da Capela Real a partir da chegada da corte passou a representar, para o compositor, conflitos de variadas ordens. D. João apreciava a música religiosa; na mesma medida, a aristocracia estava inclinada ao que Maurício Monteiro descreveu como "virtuosismo italiano" (2008, p. 36). Então,

José Maurício encontrava-se entre dois fogos: um o tangia a obedecer aos ditames de seu íntimo; o outro o compelia a satisfazer o gosto dos frequentadores da Capela. No primeiro caso, ele se via atraído pela música religiosa mais compatível com suas transcendentes finalidades, tal como ele a escrevera até ali, norteado pelos efeitos de uma formação artística calcada, sobretudo, na leitura das partituras de mestres como Haydn; no segundo, tinha de render culto ao estilo brilhante, porém vazio, dos mestres italianos em voga, que eram mais compositores de óperas do que propriamente de música religiosa, embora cultivassem os dois gêneros. (ANDRADE, 1967, p. 29)

O embate entre a música religiosa e o estilo italiano excede a dimensão íntima quando, em 1811, para sustentar a vida artística que crescia no Rio de Janeiro, o príncipe regente convoca Marcos Antonio da Fonseca Portugal, famoso pela composição de óperas e nomeado tutor - musical - de Pedro I do Brasil.

Não é possível afirmar que a predileção por Marcos Portugal seja de caráter exclusivamente racista, mas a questão da raça é latente, especialmente durante o período colonial. Um comentário feito por Louis Freycinet ${ }^{4}$ (apud ANDRADE, 1967) dá o tom da condição do músico negro carioca: "Muitas vezes ouvimos com admiração a música da Capela Real, onde quase todos os artistas são negros e cuja execução nada deixa a

\footnotetext{
${ }^{3}$ A Sé Catedral ficava ao lado do Paço imperial, utilizado como casa de despacho da corte, e também do Convento do Carmo, onde a rainha D. Maria I foi instalada.

${ }^{4}$ Louis Claude de Saulces de Freycinet $(1779$ - 1842) foi um geólogo e geógrafo francês que realizou uma expedição científica no Brasil e contratou, no Rio de Janeiro, Aimé-Adrien Taunay como ilustrador.
} 

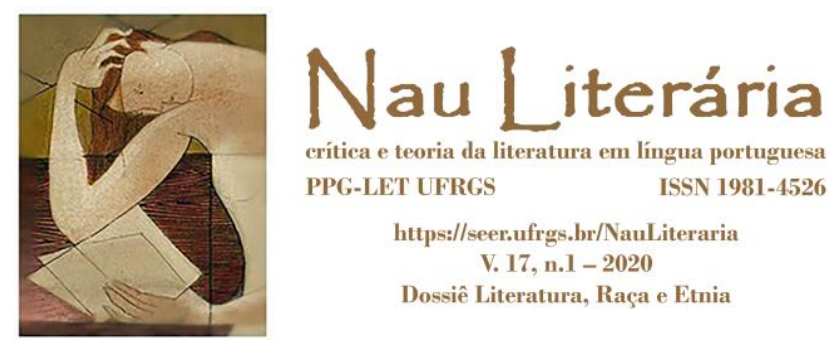

desejar.” (1967, p. 36). A citada admiração é a única resposta possível para o préconceito que determinava o negro no século XIX. E é admiração que D. João VI sente, segundo alguns autores que estudam a história da música (ANDRADE, 1967; ALMEIDA, 1926) pelas execuções que não deixam a desejar, ainda que os artistas não sejam brancos. Também nessa linha, o comentário tecido por Lange (apud SILVA, 2007) busca esclarecer que a cor da pele se consolidou como um marcador dos músicos nesse momento - fato que, em seguida, é valorizado pelo autor e considerado fundamental para o processo musical da América Portuguesa.

Lange lembra a presença do Padre José Maurício Nunes Garcia e de seu professor pardo, destacando não a sua formação religiosa, mas a cor da sua pele. O autor argumenta que as atividades musicais nesta cidade [Rio de Janeiro], assim como nos centros urbanos mineiros, foram desenvolvidas por mulatos. (SILVA, 2007, p. 25).

Enfim, essa espécie de conservatório de música em que se transformou a Sé Catedral foi destinado, inicialmente, a instruir os negros de ambos os sexos nessa arte, para que pudessem tocar em cerimônias religiosas. Com uma escola musical como a Igreja dos Carmelitas encaminhada, as atenções puderam ser destinadas aos teatros da cidade. Entre 1808 e 1813 o Teatro Régio 5 foi fundo para as - abundantes - peças líricas na capital, pois era onde se exibiam, dentre outras apresentações, óperas cantadas por Joaquina Maria da Conceição, conhecida por Lapinha, e farsas de Marcos Portugal (FAGERLAND, 2018) - entre elas, uma de texto de Domingos Caldas Barbosa (ANDRADE, 1967).

Como a vida cultural e artística do Rio de Janeiro estivesse a correr bem e a prática de frequentar teatros e missas nesta nova terra passava a fazer parte da rotina aristocrática, a cidade prosperava, atingindo, inclusive, as camadas populares. O teatro cumpria sua função educativa: a de estabelecer o local de cada um na pirâmide social. A nobreza, do lado de dentro; a massa anônima de súditos, de fora.

\footnotetext{
${ }^{5}$ Inicialmente conhecido como A Casa de Ópera de Manuel Luiz, foi um dos primeiros teatros da cidade do Rio de Janeiro. Se tornou Teatro Régio a partir da chegada da corte ao Brasil e fechou em 1813, quando foi inaugurado um novo teatro oficial, o Real Teatro São João. O autor Sérgio Moraes Rego Fagerlande (2018) faz um estudo detalhado desse processo apresentando, inclusive, desenhos da fachada e da organização do Largo do Carmo, atual Praça XV, onde se localizavam todos os prédios administrativos - o centro do poder.
} 


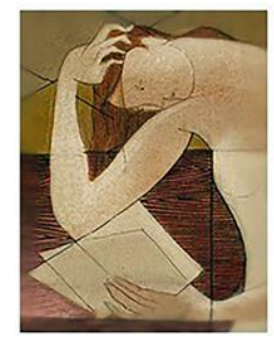

Preparada com riqueza a Casa de Ópera, concorrida em suas representações pela fidalguia opulenta e formosura aristocrática, os espetáculos deslumbravam com o esplendor o povo da colônia, que se apinhava em derredor do teatro para extasiar-se dos sons da música e ver entrar o Vice-Rei e seu estado-maior, as senhoras e os nobres senhores, que desciam de suas traquitanas pesadas e balouçantes. (MORAIS apud FEGERLANDE, 2018, p. 219).

A música tratava de civilizar a sociedade - se pensarmos que a arte religiosa foi trazida, sobretudo, por meio dos jesuítas, que se valiam da melodia para educar o espírito e afugentar os demônios, temerosos pela harmonia presente nas composições (ANDRADE, 1967). E esses supostos educadores já determinavam, nessa nova terra, uma distância necessária entre a música sacra e aquela executada para diversão, distância, essa, que será fundamental para o espaço que se criou entre a música da corte e a música popular.

Contudo, alguns anos depois da inauguração do novo Real Teatro São João, a instabilidade política trazida pela independência atingiu o campo da arte. O Real Teatro se tronou uma zona de conflito político desde a abdicação de D. Pedro I e o espetáculo lírico se tornou esporádico - segundo levantamento de Ayres Andrade, entre os anos de 1832 e 1843, "nem uma só ópera é levada à cena no Rio de Janeiro" (1967, p. 195). Além disso, as igrejas não representaram mais ambientes seguros para a música sacra, como revela a publicação de 1846 em $O$ Mercantil, jornal do período:

Observa-se em muitas igrejas do Brasil os realejos suprindo os órgãos; é um meio muito econômico na verdade, mas pouco decente; nada mais ridículo do que entrar num templo, ver sair o padre para o altar e ouvir o negro no coreto rodar o realejo, que geralmente só contém destas árias populares que nenhum cabimento deveriam ter na casa do Senhor. Entra-se em dúvida se estamos na igreja ou num Cosmorama e teatrinho de bonecos! (ANDRADE, 1967, p. 220 e 221).

Esses fatores, somados ao que foi considerado um mal da época - o escárnio e o desrespeito ao sagrado que traziam as músicas de teatro para dentro das igrejas desencadearam a descentralização da música favorecendo as práticas dos salões.

Interessante se notar como, em meio à tendência de descentralização que marca o período Regencial, a vida musical da Corte, que até então estava centralizada oficialmente, sobretudo nos espaços da Capela Imperial e no Teatro São Pedro de Alcântara, também passam por um processo de fragmentação. [...] ocorre, sobretudo a partir de 1831, uma proliferação de sociedades e agremiações recreativas que passaram 


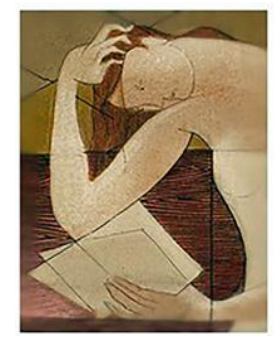

a promovê-la [música] enquanto forma de entretenimento e atividade cultural, por meio da realização de bailes e concertos ou "academias" como eram chamados na época. (p. $39-40)$.

\section{Da prática musical e dos novos instrumentos vindos da Europa}

Anunciando a boa ordem, a música sacra se contrapôs às modinhas, ao lundu e, mais tarde, à polca e ao maxixe, de forma que, durante o governo de D. João VI, percebeu-se a intensa atividade musical "distribuída basicamente em dois setores, o da Corte, onde a qualidade era imprescindível, e o de fora da Corte, em que a funcionalidade era festiva e mítica" (MONTEIRO, 2008, p. 34 e 35).

o maxixe é a mais característica das nossas danças, tendo, a princípio, ficado nas esferas mais baixas, como indigno de penetrar nos salões, onde, afinal, foi aceito, modificando os seus passos para lhe tirar o cunho obscuro. (ALMEIDA, 1926, p. 45 - 46)

A segregação entre o lundu/a modinha e os demais gêneros legitimados como oficiais se baseava na aceitação da premissa de que a música estimula virtudes, mas também vícios; a erudição vem com a primeira, e a lascívia, com a segunda. Nessas condições, se apresentavam os músicos negros e mulatos que, instruídos musicalmente, tinham os instrumentos como ofício - em qualquer uma das duas situações citadas: dentro ou fora dos ambientes formais.

A fuga da família real e a consequente instalação, no Brasil, de uma aristocracia travestida e desejante de Europa intensificou as diferenças entre as esferas públicas e privadas, uma vez que nos espaços oficiais e nos comuns circulavam pessoas e ideais diferentes. As práticas da corte se sujeitavam às regras de civilidade e etiqueta na mesma medida que os espaços populares eram regidos pela espontaneidade e pela articulação de culturas (MONTEIRO, 2008), o que contribuiu para que a modinha e o lundu corressem em paralelo aos eventos formais e religiosos. Como resultado direto da abertura dos portos às nações amigas, a circulação de produtos na colônia também foi alterada e, no que diz respeito ao campo da música, essa mudança representou o aparecimento de novos instrumentos para compor a paisagem musical no Rio de Janeiro. 

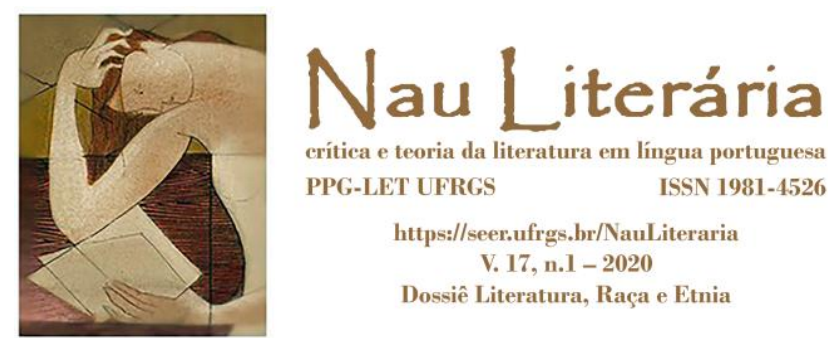

A música instrumental, nos dois anos seguintes à chegada da família real, era dominada por cravos, o que, segundo Andrade (1967), parece mudar em 1812, quando propagandas de venda de pianos proliferam nas páginas do jornal Gazeta do Rio de Janeiro, comparando o que se encontrou em 1810, quando cravos eram anunciados nas mesmas páginas. Cabe lembrar que todos os novos produtos eram de procedência inglesa, o que acentua a importância da abertura dos portos para o desenvolvimento da música. Em 1823 os cariocas conhecem o piano mecânico, como revela a publicação:

Vende-se um piano-forte de muito gosto, com muitos toques de várias músicas diferentes por ter 3 cilindros e toca por corda que lhe se dá (ANDRADE, 1967, p. 134),

E, em 1829, fala-se, na imprensa, pela primeira vez, segundo levantamento do autor, na fabricação de pianos no Rio de Janeiro. Contudo, data de 1834 a produção do primeiro piano na então capital.

O piano se consolidou como um móvel aristocrático, incumbido de um alto valor social e esteve na base das relações estabelecidas entre ter, parecer e não ser. Em outras palavras, tê-lo em casa avivava a lembrança do trabalho de escravos em carregá-lo e simbolizava bom gosto musical, ainda que essa aparência pudesse destoar da essência. A modinha foi acompanhada, no princípio, pelo cravo e, depois, pelo piano - e é assim que ela chega aos salões. O piano é um instrumento popular nas obras de Machado de Assis, aparecendo em contos e, também, nos romances tão famosos.

Para atuar na colônia não bastavam imposições, mas, antes, eram necessárias negociações. Obviamente as partes interessadas e envolvidas nessa transação cultural não ocupavam o mesmo patamar e não detinham o mesmo poder. Contudo, a paisagem sonora da cidade que se tornou o grande centro político e econômico no século XIX contou com a presença do negro, afinal, a produção musical passou diretamente pelas suas mãos. Dessa forma, a música popular brasileira do século XIX é o resultado da união de culturas negras e europeias, tendo sua maior expressão nas modinhas e lundus entoados nos centros do Brasil colônia. 

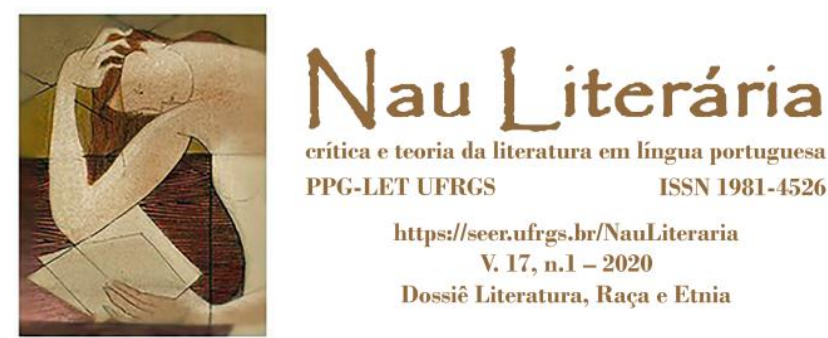

\section{Da educação pela música e pelos jornais que a veiculavam e da aparição de um autor nessas páginas}

Joaquim Maria Machado de Assis foi um escritor nascido no Rio de Janeiro no ano de 1839. De origem pobre e de descendência negra, foi

[...] autor de uma profusão de romances, novelas, contos, obras teatrais, ensaios, poesias, resenhas crônicas políticas, que foi também tipógrafo, repórter, diretor de uma revista, candidato a cargo público, fundador e primeiro presidente da Academia de Letras de seu país. (CUNHA, 1998, p. $38)$.

Publicando, principalmente, contos, atuou em diversos jornais, dos quais escolhemos $O$ Jornal das Famílias e $O$ Jornal das Senhoras, pela contribuição para com o cenário musical do Rio de Janeiro no século XIX. Das várias personalidades desse autor, Augusto Meyer (2005) destaca a humorista como a responsável pelas demais, como aquela que se sobressai pela crítica social. E é, justamente, a crítica social uma característica marcante de Machado.

O Jornal das Senhoras, publicado entre os anos de 1852 e 1855, e o Jornal das Famílias, que circulou entre 1863 e 1878, foram meios importantes de atingir o público feminino e instrui-lo de sua "missão natural", veiculando, em suas páginas, sessões de moda, de romance, de comentários culturais, de educação feminina e de música. Fazendo desta última um recurso pedagógico, os dois jornais propunham o ensino da mulher a partir do exercício musical, orientando-as a cantar e a tocar piano sempre nos espaços reservados do lar além de procurar civilizar, com isso, costumes e hábitos de uma "boa e instruída esposa". O piano se torna uma prática de etiqueta social e, ao acompanhar as modinhas, promove a socialização e a emancipação sobretudo para as mulheres que, segundo Lima (2010), podem usufruir do aprendizado formal da música como elemento obrigatório para uma boa educação.

Machado de Assis observara os benefícios da educação formal de música para o público feminino ao publicar, em 1866, o conto A pianista no Jornal das Famílias. Nas linhas dessa história, a personagem, uma professora de piano estimada e que fazia uso de sua técnica para sustentar-se e a sua mãe, ganha seu "final feliz". Assim como nos contos a serem analisados a seguir, em A pianista, nos deparamos com a trajetória de 


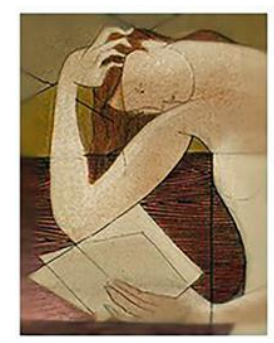

uma artista que, ainda que aponte para a parca preocupação de um autor com a representação dessa nova "classe de possíveis músicos", não deixa de ganhar suas páginas em um jornal de relativa circulação e fama.

\section{Dos contos publicados durante o século XIX}

Um levantamento detalhado das publicações de Machado de Assis feito por Patrícia Lessa Flores da Cunha (1998) contabiliza cento e sessenta contos - excluídos quarenta e cinco títulos não publicados pelas duas mais conhecidas edições das obras do autor, embora tivessem aparecido nos jornais da época. De sua lista, selecionamos $O$ machete (1878), Cantiga dos esponsais (1883) e Um homem célebre (1888). Nessas três narrativas, a música é anunciada como elemento marcante na sociedade do século XIX, e as personagens, artistas, enquanto retratos de uma época, se alinham ao cânone (e, mesmo, desejam alcançá-lo), ainda que pertençam a uma classe popular.

Apesar do autor não fazer alusão direta à cor da pele das personagens, reconhecemos contextos que permitem que elas sejam ditas negras ou mestiças. Primeiramente, vivem na miséria: em casas pobres, em regiões afastadas do centro urbano, recebendo pouco por sua arte que é a música. A casa de Pestana ${ }^{6}$, na rua do Aterrado $^{7}$, por exemplo, é descrita pelo narrador como uma "casa velha, [de] escada velha, [com] um preto velho que o servia"; a personagem tem muitos retratos na parede, mas "um só era a óleo" [que foi deixado de herança] e veste "velhos trastes, ainda do tempo de Pedro I". Romão ${ }^{8}$ reside no subúrbio em uma casa que "não era rica

\footnotetext{
${ }^{6}$ Personagem do conto Um homem célebre.

${ }^{7}$ No século XIX, a área onde hoje existe o bairro da Cidade Nova (ao longo da Av. Presidente Vargas) já foi conhecida como Mangue, Aterrado ou Caminho das Lanternas. Era uma área pantanosa e alagadiça onde corria uma grande vala que só foi drenada e saneada em 1857 com a construção de um estreito canal. A narrativa do conto se passa em 1875 quando a drenagem já havia sido feita. Contudo, o bairro continuou a ser exclusivamente povoado por negros libertos ou fugidos.

${ }^{8}$ Personagem de Cantiga dos esponsais.
} 

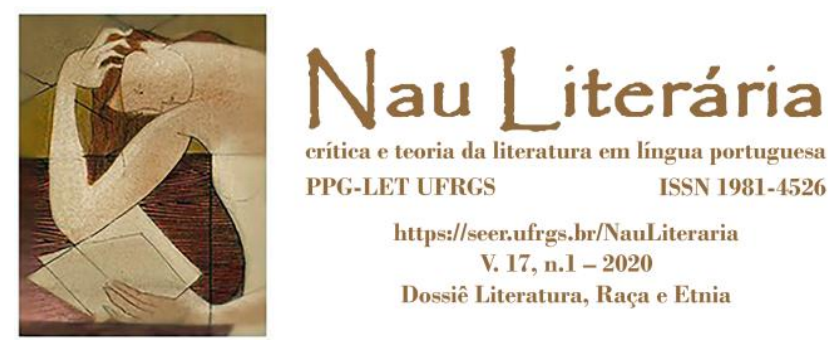

naturalmente; nem alegre", "nasceu no Valongo9, ou por esses lados”, enquanto Inácio ${ }^{10}$, homem de poucas posses, como afirma o narrador, mora em um local afastado, "alheio a sociedade que o cercava e que não o entendia", em uma casa "baixa, ainda que assaz larga e airosa".

Essas personagens revelam, também, a insatisfação dos artistas da época com a vulgaridade da música que produziam, como é o caso de Pestana e a sua relação com a polca $^{11}$, ou mesmo com a vulgaridade da recepção, como é o caso de Inácio e seu violoncelo, incompreendido pelo público e, finalmente, trocado por sua própria esposa por um machete. O necessário foi dito sobre o incentivo da música a virtudes e a vícios para que possamos perceber que é por esse princípio que se guiam esses três seres, que querem estar nesse campo da cultura, mas se encontram do outro lado da ponte - aquele lado que lhes cabe por conta do preconceito. Essa situação lembra o dilema vivido pelo padre José Maurício Nunes Garcia no início do século e citado logo no começo do presente trabalho acerca da seleção do repertório da Capela Real.

Além disso, é possível perceber a desaprovação dos músicos frente a performance do artista popular que, na figura de Barbosa ${ }^{12}$, traz o elemento "corpo" como parte da apresentação musical. Esse conflito entre vocação-produçãoperformance-recepção aparece nas palavras finais do narrador sobre a morte de Pestana - que "expirou [...] bem com os homens e mal consigo mesmo" -, mas assombra, em especial, a personagem do conto Cantiga dos esponsais, que não encontra uma forma de comunicar seus impulsos interiores aos homens através de uma composição própria. Romão rege a orquestra em uma das igrejas ${ }^{13}$ mais importantes do século XIX, mas

\footnotetext{
9 A região do Valongo (que, hoje, estaria localizada entre a Baía de Guanabara, a Avenida Marechal Floriano e a Pedra do Sal, no bairro Saúde) foi pouco povoada nos primeiros séculos de vida da cidade. A partir do século XVIII, contudo, a movimentação nessa região se intensificou por conta da comercialização de escravos que passou a ser feita nessa rua.

${ }^{10}$ Personagem de $O$ machete.

${ }^{11}$ Dança popular alemã que gerou indignação no Brasil pelo estilo de dança que propunha aproximação física dos dançarinos.

12 Personagem de $O$ machete.

${ }^{13}$ Igreja do Carmo, como aponta Machado de Assis. Essa igreja era frequentada pela Família Real.
} 

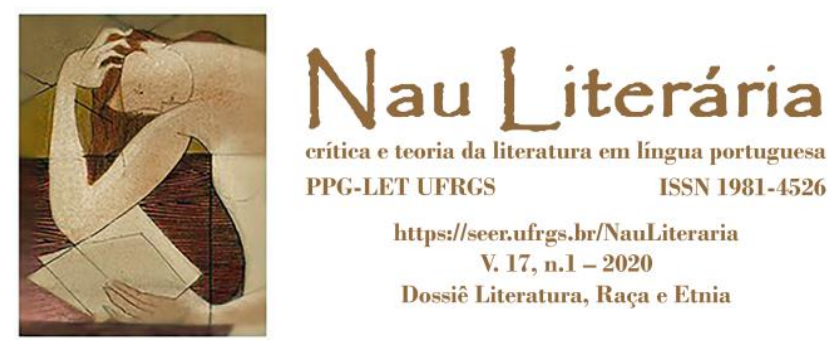

acaba encontrando, na boca do popular, o que estivera buscando para compor seu canto esponsalício no cravo.

A figura do mestre Romão merece algumas considerações, a começar pelo fato dele possuir, em 1813, um cravo - o que vem a concordar com o que Ayres Andrade encontra em sua pesquisa pelas páginas dos jornais e afirma acerca da troca do cravo pelo piano - em contraste com Pestana que, por volta de 1870, compõe em um piano. É o mesmo mestre Romão quem interage, através da música, com José Maurício. Evocar o padre regente da Capela Real em 1883, quando o conto foi publicado, transportando os leitores para o ano de 1813, quando José Maurício ainda atuava, traz à memória um grande nome da música erudita que era mulato; e esse fato, por certo, não pode ser ignorado por aqueles que advogam contrários a Machado de Assis, acusando-o de descaso para com a causa abolicionista.

Nesse período, peças eram escritas por Beethoven e Mozart (peças executadas nos teatros reais) e, um pouco mais tarde, por Brahms e Debussy, músicos que influenciam as personagens dos contos do Machado de Assis, evidenciando a preferência dos artistas da época pela peça clássica e sacra - Inácio, por exemplo, troca a rabeca pelo violoncelo após ouvir um músico alemão que veio ao Rio de Janeiro e "arrebatou o público" tocando tal instrumento; Romão tem vocação para música clássica, mesmo não sendo capaz de compô-la (e nem de compor o que fosse); e, por fim, Pestana tem muitos quadros de compositores famosos de músicas clássicas em seu “altar" junto ao piano, sendo capaz de reproduzir com perfeição a sonata de Beethoven. Tal preferência se deve por conta das oportunidades de que os artistas dispunham, no século XIX, de aprender, de produzir e mesmo de viver da música.

Portanto, os compositores e intérpretes cariocas nesse período são sujeitos ${ }^{14}$ negros ou mestiços que, mesmo sendo homens livres, frequentam salões e festas ainda como "marginais" - são artistas indigentes que vivem em periferias, frustrados e melancólicos. Sobre os citados salões, lembremos que se tratou de:

${ }^{14}$ Como Domingos Caldas Barbosa (1740-1800); José Maurício Nunes Garcia (1767-1830); Joaquina Maria da Conceição (?-?); Camila Maria da Conceição (1873-?). 


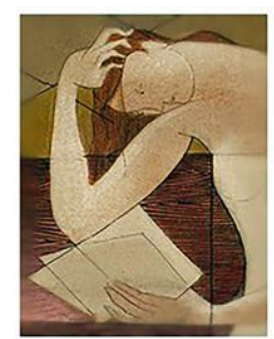

Uma tendência de descentralização dos espaços musicais na qual não apenas suas programações e conteúdos deixam de ser de alguma forma tutelados e determinados pelo Estado, como também parece haver uma prevalência de suas funções meramente "recreativas", em contraponto às suas finalidades para o "cultivo" do espírito e o desenvolvimento da civilização. (MONTEIRO, 2008, p. 40)

Esses músicos são alheios a suas realidades, uma vez que buscam, em suas composições, a erudição sob a qual foram formados - o que acaba se tornando um ideal inacessível dado o fato de eles serem "homens de cor" e pertencerem a "outro patamar social".

A música é apresentada como um ofício transmitido pela família, ou seja, uma prática não-escolarizada; e a educação, ministrada pelas instituições religiosas - fato revelado também por outros contos do mesmo autor, como Muitos anos depois (1874) e assegurada pela função exercida pela Capela Real no início do século.

O ofício de músico era legado aos negros e mestiços, mas também aos padres, o que explica a relação da música com a sacralidade e também o motivo de nossas personagens aparecerem regendo missas ou mantendo alguma relação com figuras da igreja - Inácio é filho de um "músico da imperial capela [que] ensinou-lhe os primeiros rudimentos da sua arte", e Pestana foi educado por um padre "que lhe ensinara latim e música, e que, segundo os ociosos, era o próprio pai do Pestana". Os homens brancos não têm a música por ofício - como mostra Machado de Assis nas personagens de $O$ machete: Fagundes, o subdelegado, não toca instrumentos desde que atingiu esse cargo; Amaral e Barbosa são estudantes de Direito que encontram, nos instrumentos musicais, um passatempo. E nem a música paga o suficiente para promover os artistas - mesmo Pestana, o único que "lucra" com o popular, não é considerado um homem de posses.

Por fim, alguns anos antes do final do século, em meio a reforma urbana e após a abolição da escravatura, surge o choro, que possibilita novos ofícios para as camadas populares e que tem origem no lundum. Esse estilo musical nasce nos quintais dos subúrbios cariocas e foi uma forma de executar os ritmos importados e consumidos nos salões da alta sociedade do Império, consagrando artistas como Pixinguinha, Chiquinha Gonzaga e Joaquim Callado. 

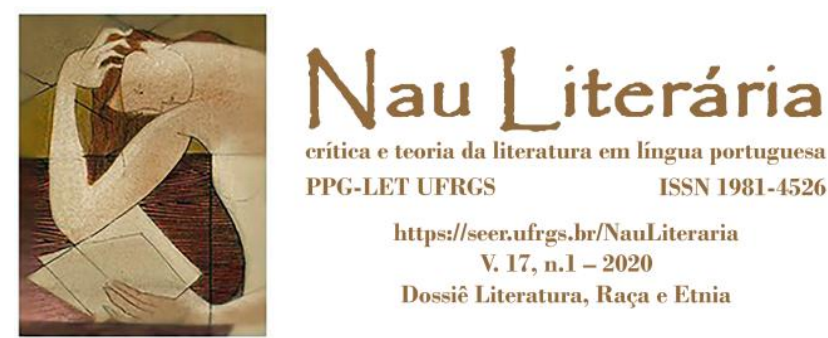

\section{Algumas conclusões}

Estudar a literatura brasileira a partir de um outro paradigma, priorizando, no que diz respeito à autoria, a raça e o gênero, reforça a premissa de que o sistema literário é excludente, já que esse "outro paradigma" será, consecutivamente - e inevitavelmente -, paralelo àquele entendido por "padrão". Contudo, a possibilidade de elencar um conjunto de autores e autoras que, por conta de marcadores biológicos, foram mantidos fora das discussões acerca do cânone se torna importante, uma vez que a grande figura da nossa literatura é Machado de Assis, um autor negro que costuma ter esse dado biográfico omitido e ser tratado alheio a essa condição de homem "de cor" na sociedade brasileira do século XIX.

Assim, parece intrigante que, mesmo reconhecendo a relevância de Machado, nossa literatura não tenha se redimido de seus preconceitos e que nossa sociedade tenha permitido, a esse conjunto de artistas, um papel "menor": a expressão enquanto músico “popular". Em outras palavras, o artista negro (quase que exclusivamente) existiu na música, como o muito citado padre José Maurício Nunes Garcia, e, nesse contexto, tratou-se de entender o termo "popular" como pejorativo.

Atentemo-nos aos fatos. Primeiro: Machado de Assis é um dos grandes nomes da literatura brasileira. Segundo: Machado de Assis foi mulato. A literatura brasileira não se estabeleceu a partir de mulatos, e esse é o terceiro fato. Portanto, tratou-se de embranquecer as produções artísticas relevantes a partir de um processo violento de apagamento dos sujeitos negros (escritores, músicos, arquitetos...); e é para isso que chamamos atenção. Não será suficiente encontrar nomes apagados pelo preconceito enquanto não pudermos pensar na diferença que essa marca, a cor da pele, provoca quando da produção ou mesmo da recepção de uma obra.

Nesse sentido, se as personagens dos contos estudados fracassam em seus objetivos enquanto músicos, são bem-sucedidas enquanto fantoches desse grande autor que trabalha nos limites do que pode - e deve - ser dito. 


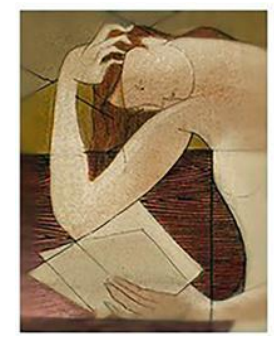

O certo é que, ao convocar o leitor, manipulando-o textualmente com esse procedimento, Machado aproveita para [...] exibir-lhe um quadro da cultura brasileira com o qual não pactua, ou, antes, sonha em modificar. (CUNHA, 1998, p. 45).

\section{Referências}

ALMEIDA, Renato. História da música brasileira. Rio de Janeiro: F. Briguiet, 1926.

ANDRADE, Ayres de. Francisco Manuel da Silva e seu tempo, 1808-1865: uma fase do passado musical do Rio de Janeiro à luz de novos documentos. Rio de Janeiro: Tempo Brasileiro, V. I e V. II, 1967.

ASSIS, Machado. Cantiga dos esponsais. Contos reunidos. Porto Alegre: Pradense, 2008. p. 300-302.

_. Um homem célebre. Contos reunidos. Porto Alegre: Pradense, 2008. p. 388-393.

. O machete. Contos reunidos. Porto Alegre: Pradense, 2008. p .553- 559.

. A pianista. Contos raros. Porto Alegre: Pradense, 2014. p. 23-50.

BARBOSA, Everton Vieira. O Rio de Janeiro e as práticas musicais em meados do século XIX.

<http://www.snh2011.anpuh.org/resources/anais/34/1401492619_ARQUIVO_Aspratica smusicaisnoseculoXIX.pdf >. Acesso em: 10 fev. 2020.

BONILLA, Rafaela. Tebas, paulista escravizado, reconhecido arquiteto 200 anos depois. Veja São Paulo, São Paulo, 10, jan., 2020. Disponível em

<https://vejasp.abril.com.br/blog/memoria/escravo-arquiteto-tebas/>.

CUNHA, Patrícia Lessa Flores da. Machado de Assis: um escritor na capital dos trópicos. Porto Alegre: IEL - Editora Unisinos, 1998.

FAGERLANDE, Sergio Moraes Rego. A Casa de Ópera e o Rio de Janeiro no século XVIII: novos espaços de liberdade. Urbana: Revista Eletrônica do Centro Interdisciplinar de Estudos sobre a Cidade. Campinas, SP, v. 10, n. 1. p. 104- 130. jan./mai. 2018.

JACKSON, Kenneth David. Machado musical: notas sobre música e escrita. Machado Assis em Linha. 2019, vol. 12, n. 26, p. 109-124.

LIMA, Edilson Vicente de. A modinha e o lundu: dois clássicos nos trópicos. Tese (Doutorado em Musicologia). São Paulo: Escola de Comunicação e Artes da Universidade de São Paulo, 2010. 

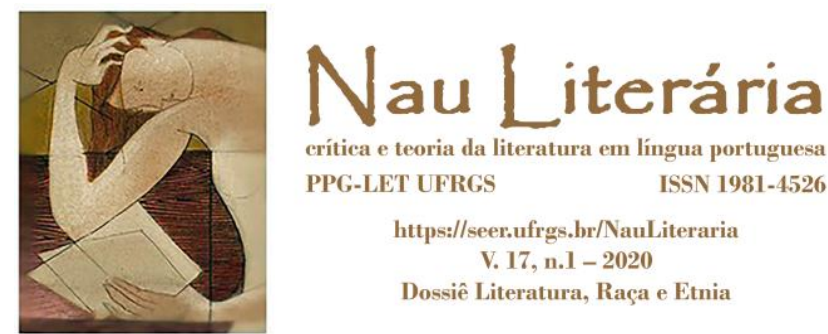

MEYER, Augusto. Machado de Assis. Porto Alegre: Instituto Estadual do Livro; Corag, 2005.

MONTEIRO, Maurício. A construção do gosto: música e sociedade na Corte do Rio de Janeiro, 1808-1821. São Paulo: Ateliê, 2008. p. 33-39.

SILVA, Janaina Girotto da. "O florão mais belo do brasil": o imperial conservatório de música do Rio de Janeiro - 1841-1865. Dissertação (Mestrado em História) Rio de Janeiro: Universidade Federal do Rio de Janeiro, 2007. 